\title{
BEAUTIFULLY BROKEN BENCHES: A TYPOLOGY OF STRATEGIC BANKRUPTCIES AND THE OPPORTUNITIES FOR POSITIVE SHAREHOLDER RETURNS
}

\author{
Jerry Paul Sheppard* \\ Simon Fraser University \\ Burnaby, British Columbia
}

\begin{abstract}
Merchants in medieval Venice who failed to pay their debts were closed by banca rotta - the breaking of the bench from which they did their business. In some cases today, bankruptcy is seen as a beautiful strategic maneuver. While there are currently some positive aspects which can be attributed to filing for bankruptcy, there is still debate as to its merits as a strategy. To allow for a more detailed understanding of the strategic bankruptcy concept, the author defines, identifies and categorizes types of bankruptcies. To address the issue of whether bankruptcy is a worthwhile strategy the author also presents a study of the effectiveness of bankruptcy in advancing long-run shareholder wealth. A sample of 155 bankruptcies was employed to study the impact of various strategies on returns to shareholders. Some types of strategies were found to result in significantly greater returns than average.
\end{abstract}

\section{Introduction}

If merchants in medieval Venice failed to pay their debts, creditors closed their operation by breaking the bench from which they did all their business. Italian for "broken bench", banca rotta, is the word from which bankrupt is derived (Cifelli, 1983). While the bankrupt party in medieval Venice saw their place of business go from commerce to kindling in moments, the situation in the United States today is different. A business' "broken bench" is not seen as a stack of splintered wood, but as a beautiful work of art. Bankruptcy, or, to be more accurate, Chapter 11 reorganization, has been viewed as a business strategy that can help turn around an ailing company. Like opera, if well performed, the Chapter 11 strategy can be a beautiful thing to behold: the corporation, assaulted by its creditors, is rescued from certain death and brought back to health by the wise ministrations of the court (Sheppard, 1992).

Like opera in Italy, Chapter 11 is certainly popular in the U.S. Over 60,000 filings and a total of $\$ 82.7$ billion in assets wound up in the U.S. bankruptcy

* Special thanks to Sharon Sheppard, Rocky and Rose Sheppard, Elaine Fairly, Mahamad Dhanani, Mark Wexler, Jean Last, Ann Winton and two anonymous reviewers for their assistance in this research. The author, however, assumes responsibility for all errors, omissions, etc. 
courts in 1990 (Duncan, 1991; Sherman, 1991). While there are potentially many desirable aspects one can attribute to filing for Chapter 11 (e.g. see Sheppard, 1992), there is disagreement as to the merits of strategically filing for bankruptcy (Flynn and Faird, 1991; Moulton and Thomas, 1993; Sirower, 1991). Furthermore, there is disagreement as to how strategic bankruptcy should be defined (Delaney, 1992; Flynn \& Faird, 1991; Moulton and Thomas, 1993).

For an intelligent discourse, a clear definition and conceptualization of strategic bankruptcy - as differentiated from non-strategic bankruptcy - are needed. It would also help to have some parameters within this conceptualization that help identify various types of strategic bankruptcies. This approach would allow one the weighing of possible merits and problems involved with each type of strategy. Thus, in this paper four questions will be addressed. One, what is strategic bankruptcy? A clearer definition and conceptualization of strategic bankruptcy will be introduced in the sections to follow. Two, how can one identify and categorize strategic bankruptcies? By being able to identify and categorize strategic bankruptcies, an improved understanding of the phenomenon can developed. Three, are certain types of bankruptcies effective in advancing the long run wealth of a company's shareholders? There may be situations where filing for bankruptcy might aid investor returns. This leads to the final question. What other conditions aid investor returns in situations where the firm files Chapter 11? Some understanding of circumstances which might make strategic bankruptcy a viable alternative can be achicved by answering this final question.

Sirower (1991) demonstrated that firms that were about to go bankrupt steadily lost value for shareholders in the year prior to the firm's filing date, and such firms steadily gained value for shareholders in the year after the Chapter 11 filing. Therefore, the strategic goal of optimizing long-run shareholder value (Hax and Majluf, 1984) could support a bankruptcy filing. On the other hand, Moulton and Thomas (1993) found little evidence to support the idea that a strategic bankruptcy was useful in optimizing long-run shareholder wealth.

This idea that a bankruptcy filing could promote shareholder wealth gave rise to the phrase strategic bankruptcy (e.g. see Cifelli, 1983). However, if the only requirement defining a strategic bankruptcy is that shareholders might benefit, then all bankruptcies can be viewed as strategic. This definition would render the phrase redundant, and therefore useless. Thus, if the phrase is to have any real meaning one needs to ask "what is strategic bankruptcy?"

\section{What Is Strategic Bankruptcy?}

According to Moulton and Thomas (1993) and Delaney (1992), strategic bankruptcy implies two things. First, a petition under Chapter 11 of the U.S. bankruptcy code is initiated by one stakeholder at the expense of others. Second, strategic bankruptcies are invoked to deal with a single problem (e.g. a lawsuit or class of lawsuits). By this logic, all bankruptcies are strategic (Moulton and Thomas, 1993), and there is some validity to this perspective. The competi- 
tive nature of the asset recovery game for creditors may create a situation where some stakeholders are favored at the expense of others. Also, the law gives some stakeholders priority over others in all bankruptcy proceedings (Brown, 1989). Finally, the need to file for bankruptcy, in the end, often appears to result from a single problem (e.g. cash flow problems, equity insolvency, creditor petitions).

However, the "all bankruptcies are strategic" perspective is not a very useful one. If all bankruptcies are strategic, then why would authors like Delaney (1992) focus only on specific filings (e.g. Texaco)? This perspective also does not tell us much about any variation which might occur within the realm of strategic bankruptcy. Given the wide variation in stakeholder groups that may be concerned with one bankruptcy as opposed to those that are concerned with another there should be different types of strategic bankruptcies.

Why are some bankruptcies labeled "strategic" and others not? A more straightforward definition of strategy may help distinguish between the two types of bankruptcy. Mintzberg (1991) gives five definitions of strategy: a plan, a ploy, a pattern, a position, and a perspective. Regarding these definitions, Sheppard (1992) has noted, Chapter 11 does not qualify as a strategy in most respects.

Bankruptcy, however, may fit two of Mintzberg's definitions of strategy: a plan and a ploy. As a plan, the strategic bankruptcy must be a "consciously intended course of action, a guideline (or set of guidelines) to deal with a situation" (Mintzberg, 1991: 12). In the case of strategic bankruptcy, the plan must deal with a specific stakeholder threat. As a ploy, the strategic bankruptcy must be a 'specific 'maneuver' intended to outwit an opponent or competitor' (Mintzberg, 1991: 13)." Daily (1994: 269), referring to earlier work by Delaney (1992) and Flynn \& Faird (1991), states that the strategic bankruptcy can be defined as "a proactive attempt by firm's management to contend with some threat posed by a stakeholder group." Delaney (1992), also notes that, in cases of strategic bankruptcy, there is an intention to promote some group of stakeholders at the expense of others.

To identify the strategic bankruptcy, one needs to go beyond the items Moulton \& Thomas (1993) and Delaney (1992) mention: that a petition is initiated by one stakeholder at the expense of others and the filing is invoked to deal with a single problem. A strategic bankruptcy must also be one in which the firm is attempting to use Chapter 11 as a ploy or a plan (Mintzberg, 1991) in a proactive fashion (Daily, 1994) to deal with some threat posed by an identifiable stakeholder group.

\section{What Is A Non-Strategic Bankruptcy?}

If one can identify strategic bankruptcies, then one must surely be able to spot non-strategic bankruptcies. Non-strategic bankruptcies may possess some of the attributes of strategic bankruptcies. Thus, differentiating one from the other may be difficult. For example, both strategic and non-strategic bankruptcies greatly impact a single identifiable stakeholder. However, with non-strategic fail- 
ures the impacted parties are usually commercial or financial creditors (e.g. suppliers or lenders, respectively). In these non-strategic cases, the debtor company seeks to obtain a straight-forward stay against the action of creditors.

As shall be seen, strategic failures typically, although not always, impact groups other than creditors. This means is that one can file a strategic Chapter 11 which targets creditors, but the objective of the filing must appear to go beyond a simple stay. In other words, to be defined as a strategic bankruptcy which targets creditors, there must be some evidence that the filing was part of a plan that the firm's managers were unable to execute pre-petition, and that the filing was being used as a ploy to force the support of creditors ${ }^{2}$.

Table 1: Strategic vs. Non-Strategic Bankrupties

\begin{tabular}{|c|c|c|}
\hline ATTRIBUTES & $\begin{array}{c}\text { NON-STRATEGIC } \\
\text { BANKRUPTCIES }\end{array}$ & $\begin{array}{c}\text { STRATEGIC } \\
\text { BANKRUPTCIES }\end{array}$ \\
\hline $\begin{array}{l}\text { Filing impacts } \\
\text { one identifiable } \\
\text { stakeholder group } \\
\text { greatly }\end{array}$ & $\begin{array}{l}\text { Usually commercial / } \\
\text { financial creditors }\end{array}$ & $\begin{array}{l}\text { Usually stakeholders other } \\
\text { than commercial / financial } \\
\text { creditors (e.g. customers). }\end{array}$ \\
\hline $\begin{array}{l}\text { Filing is at the } \\
\text { expense of others }\end{array}$ & $\begin{array}{l}\text { Impacted identifiable } \\
\text { stakeholders usually } \\
\text { assume, and accept, } \\
\text { some level of risk } \\
\text { in their relationship } \\
\text { with the bankrupt } \\
\text { corp. (e.g. Lenders } \\
\text { risk loan default). }\end{array}$ & $\begin{array}{l}\text { Impacted identifiable } \\
\text { stakeholders usually } \\
\text { do not intend to accept } \\
\text { a level of risk in their } \\
\text { relationship with the } \\
\text { bankrupt corp. (e.g. Dalkon } \\
\text { Shield I.U.D. Customers). }\end{array}$ \\
\hline $\begin{array}{l}\text { Filing deals with } \\
\text { a single problem }\end{array}$ & $\begin{array}{l}\text { Creditors are attempting } \\
\text { to seize assets used as } \\
\text { loan collateral } \\
\text { (e.g. foreclosure). }\end{array}$ & $\begin{array}{l}\text { Interference with normal } \\
\text { operations (e.g. press } \\
\text { exposure affecting govt. } \\
\text { contracts). }\end{array}$ \\
\hline $\begin{array}{l}\text { Filing may be } \\
\text { seen as a ploy } \\
\text { or plan }\end{array}$ & $\begin{array}{l}\text { Debtor is employing } \\
\text { Chapter } 11 \text { to stay the } \\
\text { creditor's actions (e.g. } \\
\text { stop foreclosure). }\end{array}$ & $\begin{array}{l}\text { Debtor employs Ch. } 11 \\
\text { to re-negotiate some } \\
\text { agreement (e.g. lease } \\
\text { agreements). }\end{array}$ \\
\hline $\begin{array}{l}\text { Filing may be a } \\
\text { proactive measure }\end{array}$ & $\begin{array}{l}\text { Debtor is faced with } \\
\text { immediate loss due to } \\
\text { stakeholder actions } \\
\text { (again, foreclosure). }\end{array}$ & $\begin{array}{l}\text { Debtor faces eventual loss } \\
\text { to stakeholder actions (e.g. } \\
\text { lawsuits overload). }\end{array}$ \\
\hline
\end{tabular}


Given the definition for strategic bankruptcy included in the above section, several subtle differences between the strategic and non-strategic filings can be noted. These differences are summarized in Table 1. In general, non-strategic bankruptcy deals with debts incurred in the normal course of business - e.g. debts owed to suppliers and lenders - and the Chapter 11 filing simply seeks to stay the creditor's actions until the firm can develop a plan for reorganization. For example, when Pettibone Corp. found itself overburdened with debt from a downturn in the construction industry, it went into Chapter 11 in order to devise a plan that would raise equity and return the company to solvency. This action is different from strategic bankruptcies, which attempt to address obligations or problems that either: (1) do not deal with these traditional creditors, or (2) deal with these creditors in ways that were not previously contemplated ${ }^{3}$.

\section{A Simple Typology Of Bankruptcies}

To uncover distinctions between types of Chapter 11 filings, a typology of bankruptcies is developed and presented here. Typologies are typically employed to provide guidance in early exploratory work (Harrigan, 1983). Early strategy research provides numerous examples of such exploratory typologies (Miles and Snow, 1978; Miller and Friesen, 1980; Rumelt, 1974). Since one of the purposes of the present study is to explore the concept of strategic bankruptcy, the use of a typology is warranted.

For a bankruptcy to be strategic, it must be targeted at a stakeholder, and be for a specific purpose. Thus, to identify strategic bankruptcies one would need to identify which stakeholders the firm was attempting to "outwit" and what specific action the firm was attempting to "thwart." Take the example of A. H. Robins. In that case, the firm intended to outwit plaintiffs of the Dalkon shield lawsuits in order to thwart their legal claims against the company. Again, strategic bankruptcy was not the simple avoidance of general creditors but something very specific.

\section{The Sample and Operationalization}

To create a bankruptcy typology, a sample of 155 companies that entered Chapter 11 between October, 1979 (when the current bankruptcy law took effect) and December, 1987 was employed. The list of failed firms was gathered by scanning Commerce Clearinghouse's Capital Changes Reporter for companies which declared bankruptcy during the period. Because the rationale behind the Chapter 11 , filings for start-ups and heavily regulated or recently deregulated firms could with high probability be attributed to non-strategic reasons, these firms were eliminated from the sample. Moody's manuals were used to identify start-up firms (those with less than 100 employees and in existence less than five years) to be eliminated. Such firms are particularly susceptible to the ills of autocratic leadership that Argenti (1976) finds critical to firm survival. These start-up firms 
are also impacted by the liability of newness (Singh and Lumsden, 1990). Heavy industry regulation or a change in the level of industry regulation would be an added factor affecting the likelihood of firm failure (Owen and Brautigam, 1980). Thus, firms in heavily regulated or recently deregulated industries were not considered. These firms were primarily involved in the industries of transportation, telecommunications, utilities, banking, insurance, medical practice, and legal practice (SIC Code Groups 40-42, 44, 48, 49, 60, 63-64 and 80-81).

For the remaining firms, business press reports about the bankruptcy filing (from the Wall Street Journal, Business Week, Barrons, Fortune, and regional business newspapers) were analyzed in order to determine the company's reason for filing. Filings classified as strategic bankruptcies had to meet four criteria:

1. There must be one identifiable stakeholder group against which the firm could be employing Chapter 11 (e.g. product users).

2. There must be a single identifiable action the stakeholder group was taking that the firm sought to thwart via its filing of Chapter 11 (e.g. collecting on lawsuits).

3. There must be a specific goal which a Chapter 11 filing could aid the firm in accomplishing (such as a reduction in lawsuit awards).

4. The filing must go beyond simply staying the actions of general creditors to collect debts.

The first two criteria address the notion of bankruptcy strategy as a ploy, the last two ensure that the bankruptcy indicates some kind of plan. All other filings were classified as non-strategic bankruptcies.

\section{Classifications}

Fifty-five of the 155 bankrupt companies in the developed list of companies possessed strategic elements. These were categorized into nine stakeholder groups. These stakeholder groups were then divided into a total of 16 subgroups based on the firm's apparent rationale for filing. These categories and subgroups are described in Table 2. 
Table 2: Typological Categories of Strategic Bankruptices Described

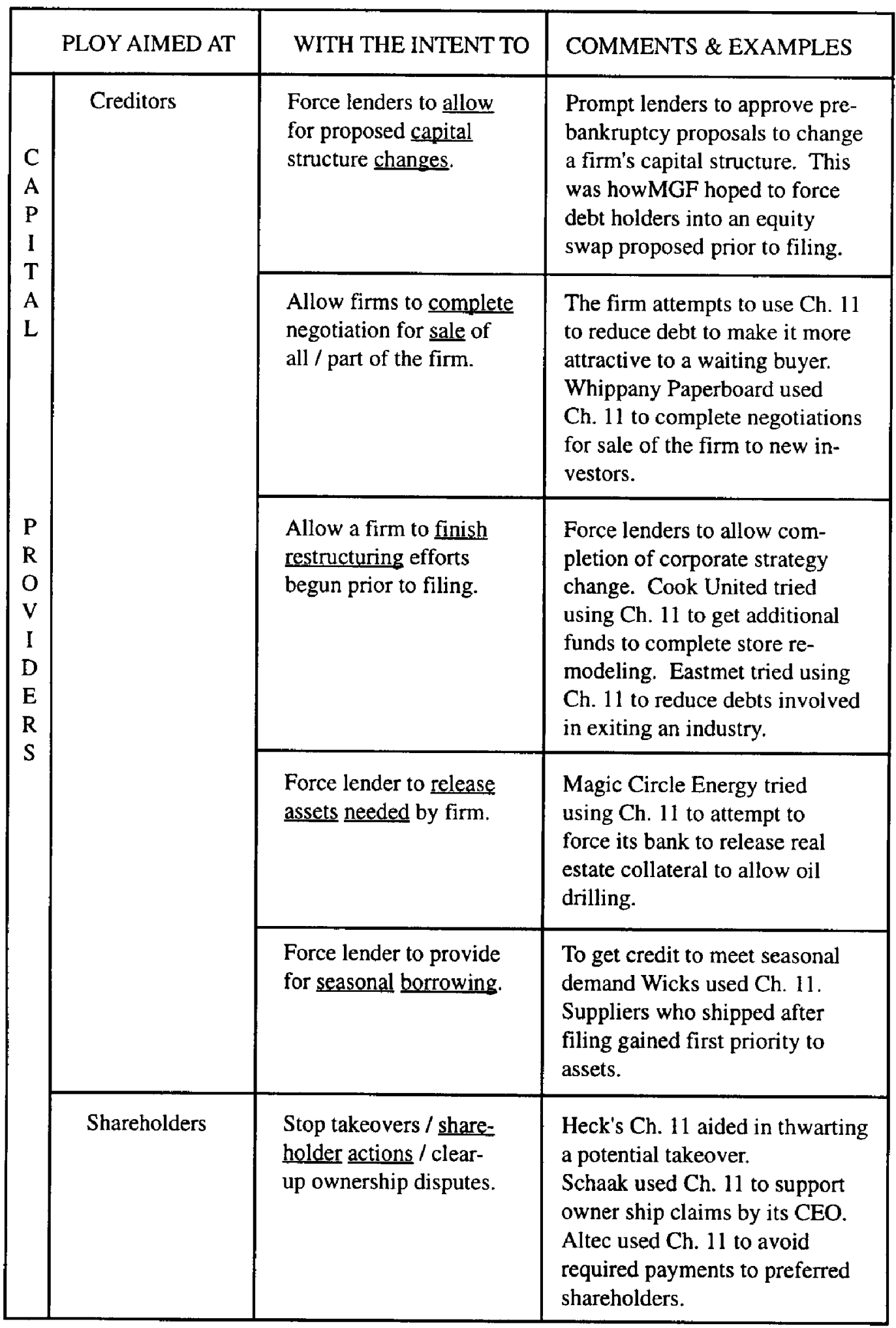


Table 2: Typological Categories of Strategic Bankruptcies Described (cont'd)

\begin{tabular}{|c|c|c|c|}
\hline & PLOY AIMED AT & WITH INTENT TO & COMMENTS \& EXAMPLES \\
\hline \multirow[t]{2}{*}{$\begin{array}{l}\text { G } \\
O \\
\text { V } \\
\text { E } \\
\text { R } \\
\text { N }\end{array}$} & \multirow[t]{2}{*}{ Government } & $\begin{array}{l}\text { Pass unfunded pension } \\
\text { costs to government } \\
\text { backed insurance agent. }\end{array}$ & $\begin{array}{l}\text { Significant unfunded pension } \\
\text { liabilities can be shed in this } \\
\text { manner. For Wheeling Corp. } \\
\text { the amount of debt shed } \\
\text { was } \$ 475 \text { million-more than } \\
30 \% \text { of their total debt. }\end{array}$ \\
\hline & & $\begin{array}{l}\text { Use legally allowed tax } \\
\text { loss carryforward as an } \\
\text { asset to get investors. }\end{array}$ & $\begin{array}{l}\text { Large losses mean future tax } \\
\text { free income. MLX had } \$ 10 \\
\text { million in assets / } \$ 150 \text { million } \\
\text { in debts after selling everything. } \\
\text { By convincing lenders to pro- } \\
\text { vide equity and back acquisi- } \\
\text { tions the firm put to use } \$ 300 \\
\text { million in loss carryforward } \\
\text { tax credits. }\end{array}$ \\
\hline \multirow{3}{*}{$\begin{array}{l}P \\
R \\
E \\
S \\
S\end{array}$} & \multirow[t]{3}{*}{ The Press } & $\begin{array}{l}\text { Remove industy scandal } \\
\text { from public attention }\end{array}$ & $\begin{array}{l}\text { Ch. } 11 \text { gets firm out of the news } \\
\& \text { back to business. Mobile } \\
\text { Home firms did so after bad } \\
\text { press on the bill padding of } \\
\text { FHA Loans. }\end{array}$ \\
\hline & & $\begin{array}{l}\text { Remove company } \\
\text { scandal from public } \\
\text { attention }\end{array}$ & $\begin{array}{l}\text { Firm gets back to business once } \\
\text { out of the press. Wedtech did } \\
\text { this once it left its government } \\
\text { procurement scandal behind. }\end{array}$ \\
\hline & & $\begin{array}{l}\text { Remove mgmt. scandal } \\
\text { from public attention }\end{array}$ & $\begin{array}{l}\text { Ch. } 11 \text { quiets news about its } \\
\text { exec.s so the firm can operate. } \\
\text { As worked with Saxon Ind. } \\
\text { after news of being looted by } \\
\text { their CEO. }\end{array}$ \\
\hline
\end{tabular}


Table 2: Typological Categories of Strategic Bankruptcies Described (cont'd)

\begin{tabular}{|c|c|c|c|}
\hline \multicolumn{2}{|c|}{ PLOY AIMED AT } & WITH INTENT TO & COMMENTS \& EXAMPLES \\
\hline $\begin{array}{l}\mathrm{M} \\
\mathrm{I} \\
\mathrm{S} \\
\mathrm{C}\end{array}$ & $\begin{array}{l}\text { Buyers \& } \\
\text { Suppliers }\end{array}$ & $\begin{array}{l}\text { Escape unprofitable } \\
\text { contracts arranged with } \\
\text { buyers or suppliers. }\end{array}$ & $\begin{array}{l}\text { Revere Copper \& Brass was } \\
\text { able to escape over-priced } \\
\text { contracts with its electric sup- } \\
\text { pliers and under-cost contracts } \\
\text { with its aluminum buyers via } \\
\text { its use of Ch. } 11 .\end{array}$ \\
\hline $\begin{array}{l}\text { I } \\
\text { L } \\
\text { E } \\
\text { G } \\
\text { A } \\
\text { L }\end{array}$ & Competitors & $\begin{array}{l}\text { Avoid damage claims } \\
\text { in single lawsuit brought } \\
\text { by a competitor. }\end{array}$ & $\begin{array}{l}\text { Re-negotiate damage awards } \\
\text { from a civil suit. Texaco used } \\
\text { Ch. } 11 \text { to avoid billions in dam- } \\
\text { ages awarded to Pennzoil. Smith } \\
\text { International used Ch. } 11 \text { to } \\
\text { avoid paying on patent infringe- } \\
\text { ment. }\end{array}$ \\
\hline $\begin{array}{l}\text { I } \\
\text { S } \\
\text { S } \\
\text { U } \\
\text { E } \\
\text { S }\end{array}$ & $\begin{array}{l}\text { Customers / } \\
\text { Prod. Users }\end{array}$ & $\begin{array}{l}\text { Avoid damange claims } \\
\text { in mass tort lawsuit } \\
\text { filed by past product } \\
\text { users. }\end{array}$ & $\begin{array}{l}\text { The firm used Ch. } 11 \text { to solve } \\
\text { many damage claims. Manville } \\
\text { used it to handle thousands of } \\
\text { asbestos related personal in- } \\
\text { jury claims. A.H. Robins used } \\
\text { it to deal with Dalkon Shield } \\
\text { claims. }\end{array}$ \\
\hline & Employees & $\begin{array}{l}\text { Escape unprofitable } \\
\text { contracts with union } \\
\text { employees. }\end{array}$ & $\begin{array}{l}\text { This is the well known ploy of } \\
\text { using Ch. } 11 \text { to void union con- } \\
\text { tracts. Among firms in the } \\
\text { present sample Tobin Packing } \\
\text { could have benefited from this } \\
\text { use of Ch. } 11 \text {. }\end{array}$ \\
\hline & Lessors & $\begin{array}{l}\text { Escape unprofitable } \\
\text { long term leases. }\end{array}$ & $\begin{array}{l}\text { Renters can get out of un- } \\
\text { profitable leases. Flannigan's } \\
\text { Enterprises was able to re- } \\
\text { negotiate over priced leases via } \\
\text { Ch. } 11 \text {. By using Ch. } 11 \text {, HRT } \\
\text { Industries was able to shut down } \\
55 \text { of its } 192 \text { retail outlets and } \\
\text { regain profitability. }\end{array}$ \\
\hline
\end{tabular}


To create a more parsimonious set of categories, the nine stakeholder groups in Table 2 have been sorted into four clusters based on common themes (see Sheppard, 1994a for further details). The Capital Providers cluster addressed cases where the bankruptcy strategy thwarted the actions of shareholders or impacted the actions of creditors in ways that are not straightforward stays. The Government cluster dealt with those cases where the bankruptcy strategy involved the firm receiving some benefit from the government which made the firm's continued existence more likely. The Press cluster involved cases where a firm was connected to a scandal, and the bankruptcy filing removed the firm from public scrutiny and allowed it to get back to business. Finally, the Miscellaneous / Legal Issues cluster concerned those firms employing the bankruptcy strategy to resolve some legal issue involving a contractual obligation (contracts, leases, union agreements) or an implied contractual obligation (fair trade, implied warranties of product merchantability).

The remaining sample consisted of 100 non-strategic bankrupt companies. A detailed list of the non-strategic bankrupt companies is included in Appendix 1. All companies involved in strategic bankruptcies, and the groups to which they belong, are included in Table 3 .

Table 3: List of Strategic Bankrupt Firms by Type

\begin{tabular}{|c|c|c|c|c|c|}
\hline \multicolumn{2}{|c|}{ Ploy Aimed at } & Intended Action & \multicolumn{3}{|c|}{ Companies and Filing Year: } \\
\hline \multirow{5}{*}{ Providers } & \multirow[t]{5}{*}{ Creditors } & $\begin{array}{l}\text { Allow Cap. } \\
\text { Change }\end{array}$ & $\begin{array}{l}\text { Global } \\
\text { Marine '86 }\end{array}$ & $\begin{array}{l}\text { MGF } \\
\text { Oil '84 }\end{array}$ & Salant ' 85 \\
\hline & & $\begin{array}{l}\text { Complete } \\
\text { the Sale of } \\
\text { the Company }\end{array}$ & $\begin{array}{l}\text { American } \\
\text { Advent. '86 } \\
\text { Crompton } \\
\text { ' } 84\end{array}$ & $\begin{array}{l}\text { Roberts \& } \\
\text { Porter '83 } \\
\text { Transcon. } \\
\text { Energy '84 }\end{array}$ & $\begin{array}{l}\text { Vector } \\
\text { Graphic '85 } \\
\text { Whippany } \\
\text { Paper '80 }\end{array}$ \\
\hline & & $\begin{array}{l}\text { Finish a } \\
\text { Restructuring } \\
\text { Previously } \\
\text { Begun }\end{array}$ & $\begin{array}{l}\text { Cook } \\
\text { United '84 } \\
\text { Eastmet '86 } \\
\text { JAMCO } \\
\text { Ltd. '87 }\end{array}$ & $\begin{array}{l}\text { Mesta } \\
\text { Machine '83 } \\
\text { Newbery '87 } \\
\text { Richton } \\
\text { Internl. '80 }\end{array}$ & $\begin{array}{l}\text { Sambos } \\
\text { Resturant } \\
\text { '81 } \\
\text { White } \\
\text { Motor' } 80\end{array}$ \\
\hline & & $\begin{array}{l}\text { Release } \\
\text { Assets }\end{array}$ & $\begin{array}{l}\text { Computer } \\
\text { Depot ' } 86\end{array}$ & $\begin{array}{l}\text { Magic } \\
\text { Circle } 85\end{array}$ & \\
\hline & & $\begin{array}{l}\text { Seasonal } \\
\text { Borrowings }\end{array}$ & \begin{tabular}{|l} 
New \\
England \\
Fish '80 \\
Steiger \\
Tractor'866
\end{tabular} & $\begin{array}{l}\text { Sam } \\
\text { Soloman } \\
\text { '80 } \\
\text { Wickes } \\
\text { Co.s '82 }\end{array}$ & \\
\hline
\end{tabular}


Table 3: List of Strategic Bankrupt Firms by Type (cont'd)

\begin{tabular}{|c|c|c|c|c|c|}
\hline \multicolumn{2}{|c|}{ Ploy Aimed at } & \multirow{2}{*}{$\begin{array}{l}\text { Intended Action } \\
\begin{array}{l}\text { Stop In- } \\
\text { vestor Act }\end{array}\end{array}$} & \multicolumn{3}{|c|}{ Companies and Filing Year: } \\
\hline & $\begin{array}{l}\text { Share- } \\
\text { holder }\end{array}$ & & Altec ' 83 & Heck's '87 & $\begin{array}{l}\text { Schaak } \\
\text { Electric. } \\
\text { ' } 85\end{array}$ \\
\hline \multirow[t]{2}{*}{$\begin{array}{l}\text { Govern- } \\
\text { ment }\end{array}$} & \multirow[t]{2}{*}{$\begin{array}{l}\text { Govern- } \\
\text { ment }\end{array}$} & $\begin{array}{l}\text { Pension } \\
\text { Costs }\end{array}$ & LTV ' 86 & $\begin{array}{l}\text { Phoenix } \\
\text { Steel ' } 83\end{array}$ & $\begin{array}{l}\text { Wheeling } \\
\text { Pitts. } 85\end{array}$ \\
\hline & & $\begin{array}{l}\text { Tax Loss } \\
\text { Carry- } \\
\text { forwards }\end{array}$ & $\begin{array}{l}\text { Allis- } \\
\text { Chalmers } \\
\text { ' } 87 \\
\text { Itel Corp. } \\
\text { ' } 81\end{array}$ & $\begin{array}{l}\text { McLouth } \\
\text { Steel '81 } \\
\text { Northwest } \\
\text { Eng. '83 }\end{array}$ & \\
\hline \multirow[t]{3}{*}{ Press } & \multirow[t]{3}{*}{ Press } & $\begin{array}{l}\text { Industry } \\
\text { Scandal }\end{array}$ & $\begin{array}{l}\text { Commodore } \\
\text { Corp. ' } 85 \\
\text { Conner } \\
\text { Homes ' } 87\end{array}$ & $\begin{array}{l}\text { Mobile } \\
\text { Home Ind. } \\
\text { ' } 84 \\
\text { Tidwell } \\
\text { Ind.s ' } 85\end{array}$ & \\
\hline & & $\begin{array}{l}\text { Company } \\
\text { Scandal }\end{array}$ & $\begin{array}{l}\text { Coleman } \\
\text { American } \\
' 80 \\
\text { Mego } \\
\text { Internatnl. } \\
\text { ' } 82 \\
\end{array}$ & $\begin{array}{l}\text { National } \\
\text { Paragon } \\
\text { ' } 85 \\
\text { Swanton } \\
\text { ' } 85\end{array}$ & $\begin{array}{l}\text { Wedtech } \\
\text { '86 }\end{array}$ \\
\hline & & $\begin{array}{l}\text { Mgmt. } \\
\text { Scandal }\end{array}$ & Rusco '81 & $\begin{array}{l}\text { Saxon } \\
\text { Industries } \\
\text { ' } 84\end{array}$ & \\
\hline Misc./ & $\begin{array}{l}\text { Buyf } \\
\text { Supply }\end{array}$ & $\begin{array}{l}\text { Avoid } \\
\text { Contracts }\end{array}$ & $\begin{array}{l}\text { Revere } \\
\text { Copper ' } 82\end{array}$ & & \\
\hline $\begin{array}{l}\text { Legal } \\
\text { Issues }\end{array}$ & $\begin{array}{l}\text { Com- } \\
\text { petitors }\end{array}$ & $\begin{array}{l}\text { Avoid One } \\
\text { Lawsuit }\end{array}$ & $\begin{array}{l}\text { Smith } \\
\text { Interntnl. } \\
' 86\end{array}$ & $\begin{array}{l}\text { Texaco } \\
' 87\end{array}$ & \\
\hline
\end{tabular}


Table 3: List of Strategic Bankrupt Firms by Type (cont'd)

\begin{tabular}{|l|l|l|l|l|l|}
\hline \multicolumn{2}{|c|}{ Ploy Aimed at } & Intended Action & \multicolumn{4}{|l|}{ Companies and Filing Year: } \\
\hline \multirow{4}{*}{} & $\begin{array}{l}\text { Prod. } \\
\text { Users }\end{array}$ & $\begin{array}{l}\text { Avoid } \\
\text { Mass Torts }\end{array}$ & $\begin{array}{l}\text { Manville } \\
\text { '82 }\end{array}$ & $\begin{array}{l}\text { Robins } \\
\text { (A.H.) '85 }\end{array}$ & $\begin{array}{l}\text { UNR } \\
\text { Ind.5 '82 }\end{array}$ \\
\cline { 2 - 6 } & $\begin{array}{l}\text { Employ- } \\
\text { ees }\end{array}$ & $\begin{array}{l}\text { Union } \\
\text { Agreements }\end{array}$ & $\begin{array}{l}\text { Tobin } \\
\text { Packing '81 }\end{array}$ & & \\
\cline { 2 - 6 } & Lessors & $\begin{array}{l}\text { Void } \\
\text { Leases }\end{array}$ & $\begin{array}{l}\text { Flannigan's } \\
\text { Ent. '85 }\end{array}$ & $\begin{array}{l}\text { HRT Ind.s } \\
\text { '82 }\end{array}$ & $\begin{array}{l}\text { Lafaytte } \\
\text { Radio '80 }\end{array}$ \\
\hline
\end{tabular}

\section{Returns To Shareholders}

The next step of the research involved a determination of how well the company performed from the shareholders' point of view. The reason shareholders were selected was as follows. Since common shareholders are the last in line to receive anything after a bankruptcy, one would assume that if shareholders received anything, creditors - as well as a wide variety of other stakeholders would also have obtained something. Thus, the needs of a great many stakeholders would likely have been addressed if common shareholders received some net benefit from the filing. Of concern here, however, are the shareholders. Since managers and directors - in theory - have a responsibility toward shareholders, one would assume that entering into Chapter 11 (particularly, the "strategy" of entering Chapter 11) would be in the shareholders' best interest.

To determine what happened to these Chapter $11 \mathrm{firms,}$ computer searches of several databases were run. In addition, the Commerce Clearinghouse's Capital Changes Reporter and Financial Information's Directory of Obsolete Securities were employed to trace securities. Capital Changes Reporter, Moody's manuals and press reports were searched to ascertain what stock conversions (i.e. pre-bankruptcy shares traded in for new shares) and dividends had been issued since the firm's Chapter 11 filing. Finally, Standard \& Poors' Directory of Corporate Officers \& Directors indexes were cross checked in order to trace firm names since, in an effort to 'start over', firms will sometimes change their name. Appendix 2 presents the list of the firms that changed their names.

Returns to shareholders were calculated to address the question, "Did the move into Chapter 11 improve the long-run financial well-being of the shareholders?" To calculate returns to shareholders, the share price on the day prior to filing was compared to the share price at the end of 1992. Annual returns to shareholders were calculated as follows: 


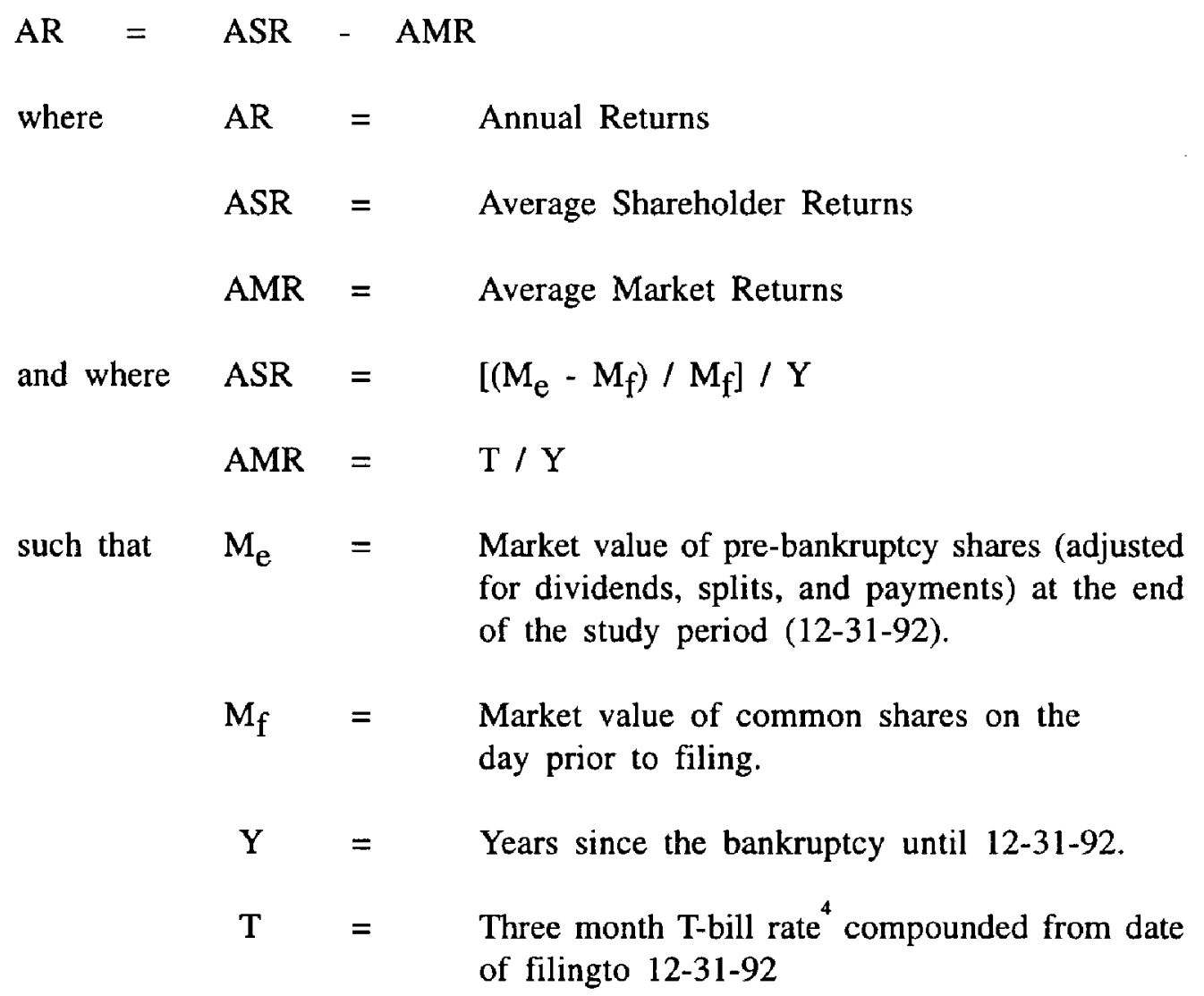

Sirower (1991) observed that the price immediately prior to filing is the lowest price a stock will possess. Both Sirower (1991) and Hambrick and D'Aveni (1988) note that this is the point at which the organization's downward spiral halts, that it is possible for conditions to improve from there onward, and that the value of the company to shareholders should also improve.

Over half the firms in the sample had a $-100 \%$ return to shareholders; i.e. their stock was worthless. About $40 \%$ of the strategic bankruptcies and about $65 \%$ of the non-strategic bankruptcies were worthless. As shown in Table 4, this difference in worthless rates is significant $(p<.01)$. Only 14 of the 155 bankruptcies in the sample (about $9 \%$ ) resulted in a return to shareholders that was positive relative to the market rate. The majority of these 14 companies utilized strategic bankruptcy. Ten of the positive return companies $(72 \%)$ were strategic bankruptcies, four were non-strategic (28\%). This difference in positive return rates is significant (cross-tabs $\mathrm{Chi}^{2}$ of $7.05, p<.01$ ) - as shown in Table 4. 
Table 4: Worthless vs. Non-Worthless Shares / Positive vs. Non-Positive Returns

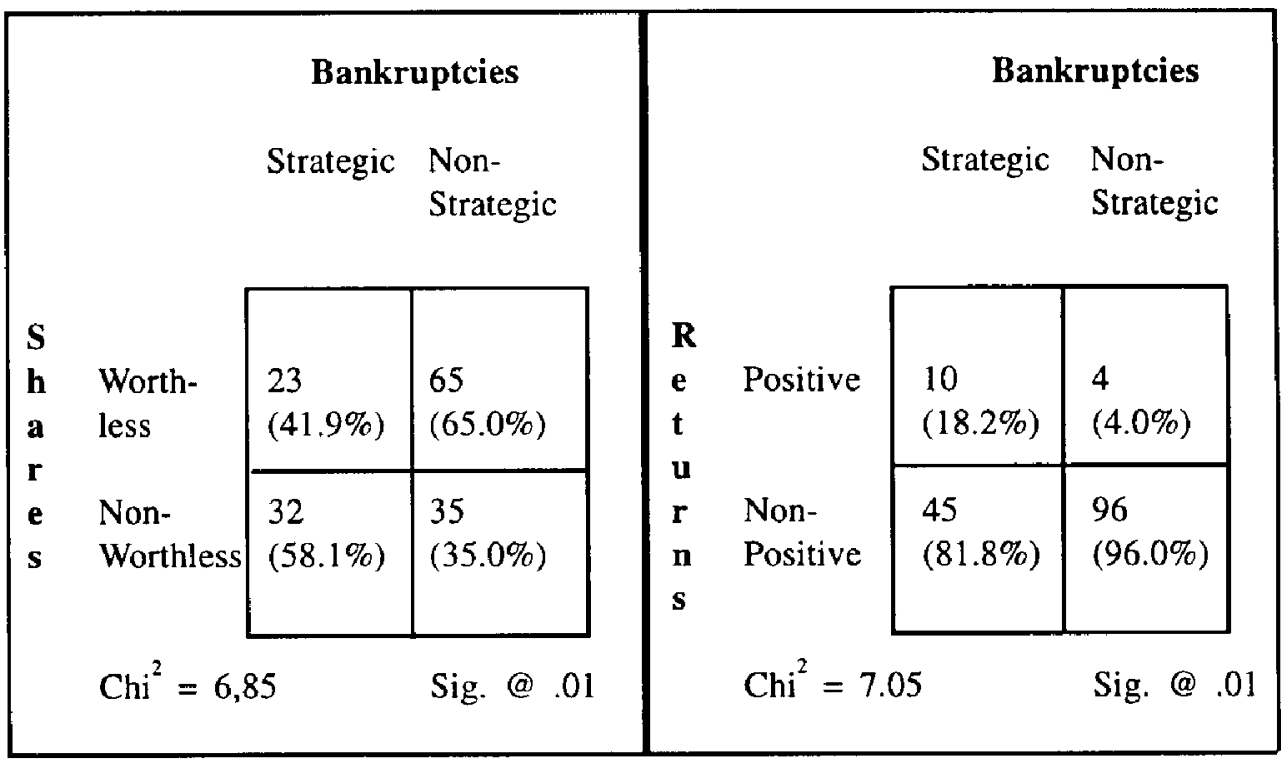

Annual returns ${ }^{5}$ for the 100 non-strategic bankruptcies in the sample averaged -3.923 (with a standard deviation of 1.94). The 55 strategic bankruptcies averaged an annual return of -1.175 rate (with a standard deviation of 7.94). The returns for the two groups were compared via a test of means - a T-test (not an uncommon test for bankruptcy data; see Sheppard, 1994b). Strategic bankruptcies, on average, had a significantly higher return to shareholders than the non-strategic group $(\mathrm{T}=2.53, p<.05)$. However, neither type of bankruptcy produced an above market rate of return since the returns for both groups are negative.

While both strategic and non-strategic bankruptcies result in negative returns, there may be some subgroups of strategic failures which create positive returns. In order to investigate this possibility the one way Analysis of Variance (ANOVA) shown in Table 5 was performed. 
Table 5: ANOVA Results Using Four Clusters of Strategic Bankruptcies

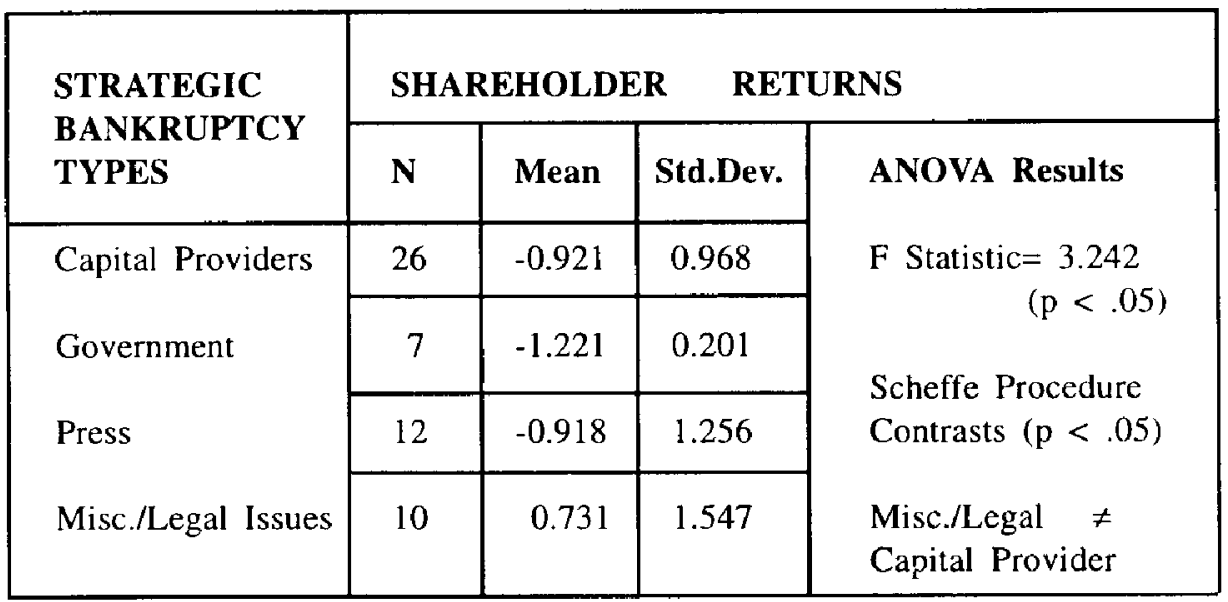

The results of the Scheffe procedure shown in Table 5 demonstrate that the firms which filed for a strategic bankruptcy when dealing with a Miscellaneous / Legal Issue had significantly different returns from those firms dealing with capital providers $(p<.01)$. While the Miscellaneous / Legal Issues group was the only one in which there were positive returns to shareholders, the ANOVA does not tell us whether the rate of return was significantly better than what could have been achieved in the market over the same time frame. To investigate whether this group of strategic bankrupts performed at better than the market rate, a pairwise T-test comparing average shareholder returns to average market returns was performed. Although firms in this group, on average, out-performed the market rate of return, the difference was not significant (pairwise $T$ of 1.36 was not significant at .1). Within the Miscellaneous / Legal cluster, only firms fending off a single lawsuit had returns significantly higher than market $(p<.01$ via pairwise T-test comparing average shareholder returns to average market returns).

Very few strategic bankruptcies had higher than market rates of return. Many categories within the set of strategic bankruptcies had lower than market rates of return". Thus, one is tempted to discard the idea of Chapter 11 filing as a useful strategic ploy. However, it is possible that effective use of bankruptcy as a strategy may be contingent upon some other factors. To address this possibility, a final test was run.

\section{Other Possible Conditions That May Impact Investor Returns}

To investigate the possible impact of other factors related to returns from bankruptcy, two variables were studied: (1) the firm's size at filing, and (2) the 
company's equity at filing. While this list is not exhaustive, given the exploratory nature of the present research, it should be a sufficient starting point from which to evaluate some contingencies which might suggest that the use of strategic bankruptcy can lead to positive shareholder returns.

\section{Corporate Size}

Firm size has been identified as one of the most important variables that impact the relationship between strategy and performance (Hoffer, 1975; Smith, Guthrie and Chen, 1989). Moulton and Thomas (1993) found that firm size was the most important variable in determining whether companies successfully reorganized. Firm size has long been recognized as an important determinant for organizational survival in the Population Ecology literature (for a review see Singh and Lumsden, 1990). As well, Finance literature has long been concerned with attempting to control for firm size effects in failure studies due to the impact firm size may have on survival likelihood (e.g. see Altman, 1968).

While it is thus important to include size as potential factor in determining the outcome of a Chapter 11 filing, the direction of the relationship between firm size and survival is debatable. Large firms are typically viewed as more likely to be successful. Moulton and Thomas' (1993) research showed that large firms are more likely than small firms to survive Chapter 11 reorganization intact. The likelihood of failure among small firms is well known in the Population Ecology literature as "the liability smallness" (Singh and Lumsden, 1990). However, smallness may not always be a liability. A small firm may have the advantage of quicker response to environmental change, because smaller firms may be organized in a less mechanistic manner and their response to external threats may thus be quicker than that of a larger organization (Staw, Sandelands and Dutton, 1981; Sutton and D'Aunno, 1989).

In order to be consistent with Moulton and Thomas' (1993) study, the measure of size employed here was firm asset size. The list of 155 sample firms was divided into small versus large firms. Small firms had less than the median $\$ 49$ million in assets; large firms had more than the median $\$ 49$ million in assets.

\section{Company Equity}

Company equity may also impact a company's response to threats. Equity can be considered a form of "organizational slack" (Sheppard, 1994b). Firms lacking slack resources may be more likely to encounter managerial paralysis or rigidity (Smart and Vertinsky, 1977; Staw, et. al., 1981) when the need for change is critical - as it is in reorganization. If such rigidity occurs, shareholder value will be dissipated since it is unlikely that management will make timely decisions that could halt the company's downward spiral in its earlier stages (Hambrick and D'Aveni, 1988). In addition, part of the logic behind the enactment of the 
1978 bankruptcy law was to encourage companies to file earlier, while they still had some equity from which to rebuild the firm (Cifelli, 1983). If Congress was correct in its estimation that early filing companies are the ones with sufficient equity bases to survive bankruptcy, then equity would be an important variable in determining reorganization success likelihood.

The ratio of equity over total assets was used as the measure of a firm's resource base. For financial institutions, net worth over total assets is also a general indication of solvency (Mun and Garcia, 1983). Pinches and Mingo (1973) and Chen and Shimerda (1981) also mention this ratio as an important, useful one. Therefore, the list of 155 firms was divided into low versus high equity firms. Low equity firms had less than a median equity to asset ratio of $9.1 \%$; high equity firms had more than a median equity to asset ratio of $9.1 \%$.

\section{Test of the Impact of Size and Equity Base}

To evaluate how the two factors of size and equity base - along with strategy - impacted the returns provided to shareholders, an ANOVA was performed. Results of the ANOVA are shown in Table 6. Table 6 also notes the group which had the highest returns within each category. These high return groups would most obviously be preferred by shareholders (detailed returns for all groups are included in Appendix 3).

Table 6: ANOVA Results by Type of Bankruptcy, Size, Equity and Corporate Purchase

\begin{tabular}{|c|c|c|c|c|c|c|}
\hline \multirow{2}{*}{$\begin{array}{l}\text { ANOVA } \\
\text { Results }\end{array}$} & \multirow{2}{*}{$\begin{array}{l}\text { Annual } \\
\text { Shareholder } \\
\text { Returns }\end{array}$} & \multicolumn{2}{|c|}{ F-Statistic } & \multicolumn{3}{|c|}{ Highest Return Group } \\
\hline & & $\mathbf{F}$ & Sig. & Group & $\mathbf{N}$ & Mean \\
\hline \multicolumn{2}{|c|}{ Main Effects } & 8.22 & .001 & & & \\
\hline \multicolumn{2}{|l|}{ Strategy } & 9.29 & .010 & $\begin{array}{l}\text { Strategic } \\
\text { Bankruptcies }\end{array}$ & 55 & -1.17 \\
\hline \multicolumn{2}{|l|}{ Size } & .03 & & $\begin{array}{l}\text { Large } \\
\text { Companies }\end{array}$ & 77 & -2.62 \\
\hline \multicolumn{2}{|l|}{ Equity } & 5.91 & .020 & $\begin{array}{l}\text { High Equity } \\
\text { Companies }\end{array}$ & 77 & -2.18 \\
\hline
\end{tabular}


Table 6: AVOVA Results by Type of Bankruptcy, Size, Equity and Corporate Purchase (cont'd)

\begin{tabular}{|c|c|c|c|c|c|}
\hline \multirow{2}{*}{$\begin{array}{cl}\text { ANOVA } & \text { Annual } \\
\text { Results } & \text { Shareholder } \\
& \text { Returns }\end{array}$} & \multicolumn{2}{|c|}{ F-Statistic } & \multicolumn{3}{|c|}{ Highest Return Group } \\
\hline & $\mathbf{F}$ & Sig. & Group & $\mathbf{N}$ & Mean \\
\hline Two-way Interactions & 1.26 & & & & \\
\hline Strategy and Size & 0.03 & & Strategic / Small & 19 & -0.88 \\
\hline Strategy and Equity & 3.62 & .060 & $\begin{array}{l}\text { Strategic / High } \\
\text { Equity }\end{array}$ & 28 & 0.53 \\
\hline Size and Equity & 0.07 & & $\begin{array}{l}\text { Large / High } \\
\text { Equity }\end{array}$ & 37 & -1.70 \\
\hline Three-way Interactions & 0.57 & & & & \\
\hline Strategy, Size and Equity & & & $\begin{array}{l}\text { Strategic / Small } \\
\text { High Equity }\end{array}$ & 11 & 1.07 \\
\hline
\end{tabular}

The ANOVA results show that the main effects were significant $(p<.001)$. In particular, there was a statistically significant relationship between annual shareholder returns, strategy and equity base $(p<.05)$. Corporate size was the only factor not significantly related to returns. Although strategic bankruptcies, large companies and high equity companies all fared well, none of these groups, on average, had returns that exceeded the market rate of return (as shown by their negative return figures).

The two-way interaction between strategy and equity in the ANOVA was of minor significance $(F=3.62, p<.1)$. Each two-way interaction creates four possible sub-groups. Thus, strategy and equity create: (1) low equity, non-strategic bankruptcies, (2) low equity, strategic bankruptcies, (3) high equity, non-strategic bankruptcies and (4) high equity, strategic bankruptcies. Thus, Table 6 also shows which sub-group had the highest returns for each interaction. As shown in Table 6. Strategic / High Equity companies had positive - above market - returns to shareholders. However, a pairwise T-test comparing average shareholder returns to average market returns showed that the returns these for these sub-groups of bankrupt companies were not significantly greater than the market rate of return over the same period $(p<1)$. Three way interactions in the ANOVA were not significant $(p<.1)$. 


\section{Results Summary}

Generally, the results of the present study show that strategic bankruptcies out-perform their non-strategic counterparts. Impacts from other factors are shown in Table 7.

Table 7: Summary of Results

\begin{tabular}{|c|c|c|c|}
\hline & $\begin{array}{l}\text { Shareholder Return for } \\
\text { all Strategic Bankrupt- } \\
\text { cies }\end{array}$ & Results & Comments \\
\hline \multirow{2}{*}{$\begin{array}{l}\text { A } \\
\text { L } \\
\text { L }\end{array}$} & $\begin{array}{l}\text { Did firms filing for stra- } \\
\text { tegic bankruptcy have } \\
\text { higher rates of return } \\
\text { than non-strategic firms? }\end{array}$ & Yes & $\begin{array}{l}\text { T-test shows a significant dif- } \\
\text { ference between the two } \\
\text { groups }(p<.05)\end{array}$ \\
\hline & $\begin{array}{l}\text { Did firms filing for stra- } \\
\text { tegic bankruptcy have } \\
\text { higher than the market } \\
\text { rate of return? }\end{array}$ & No & $\begin{array}{l}\text { The mean for strategic bank- } \\
\text { ruptcies was below the } \\
\text { market rate of return. }\end{array}$ \\
\hline \multirow[b]{2}{*}{$\begin{array}{l}\mathrm{T} \\
\mathrm{Y}\end{array}$} & $\begin{array}{l}\text { Shareholder Return by } \\
\text { Strategic Bankruptcy } \\
\text { Type }\end{array}$ & & \\
\hline & $\begin{array}{l}\text { Did any types of stra- } \\
\text { tegic bankruptcies have } \\
\text { higher rates of return } \\
\text { than other types? }\end{array}$ & Yes & $\begin{array}{l}\text { ANOVA Scheffe Procedure } \\
\text { Contrast rate Misc. } / \text { Legal } \neq \\
\text { Capital Provider }(\mathrm{p}<.05)\end{array}$ \\
\hline $\begin{array}{l}\mathrm{P} \\
\mathrm{E}\end{array}$ & \multirow{2}{*}{$\begin{array}{l}\text { Did any types of stra- } \\
\text { tegic bankruptcies have } \\
\text { higher than market rates } \\
\text { of return }\end{array}$} & One & $\begin{array}{l}\text { Misc. / Legal had positive } \\
\text { returns, but not significant } \\
\text { (pairwise } \mathrm{T}: \mathrm{p}<.1 \text { ) }\end{array}$ \\
\hline & & $\begin{array}{l}\text { (one small } \\
\text { group) }\end{array}$ & $\begin{array}{l}\text { Misc. / Legal Issues firms } \\
\text { trying to avoid I lawsuit } \\
\text { had significantly higher than } \\
\text { market returns (pairwise } \\
\text { T: } p<.01 \text { ). }\end{array}$ \\
\hline
\end{tabular}


Table 7: Summary of Results (cont'd)

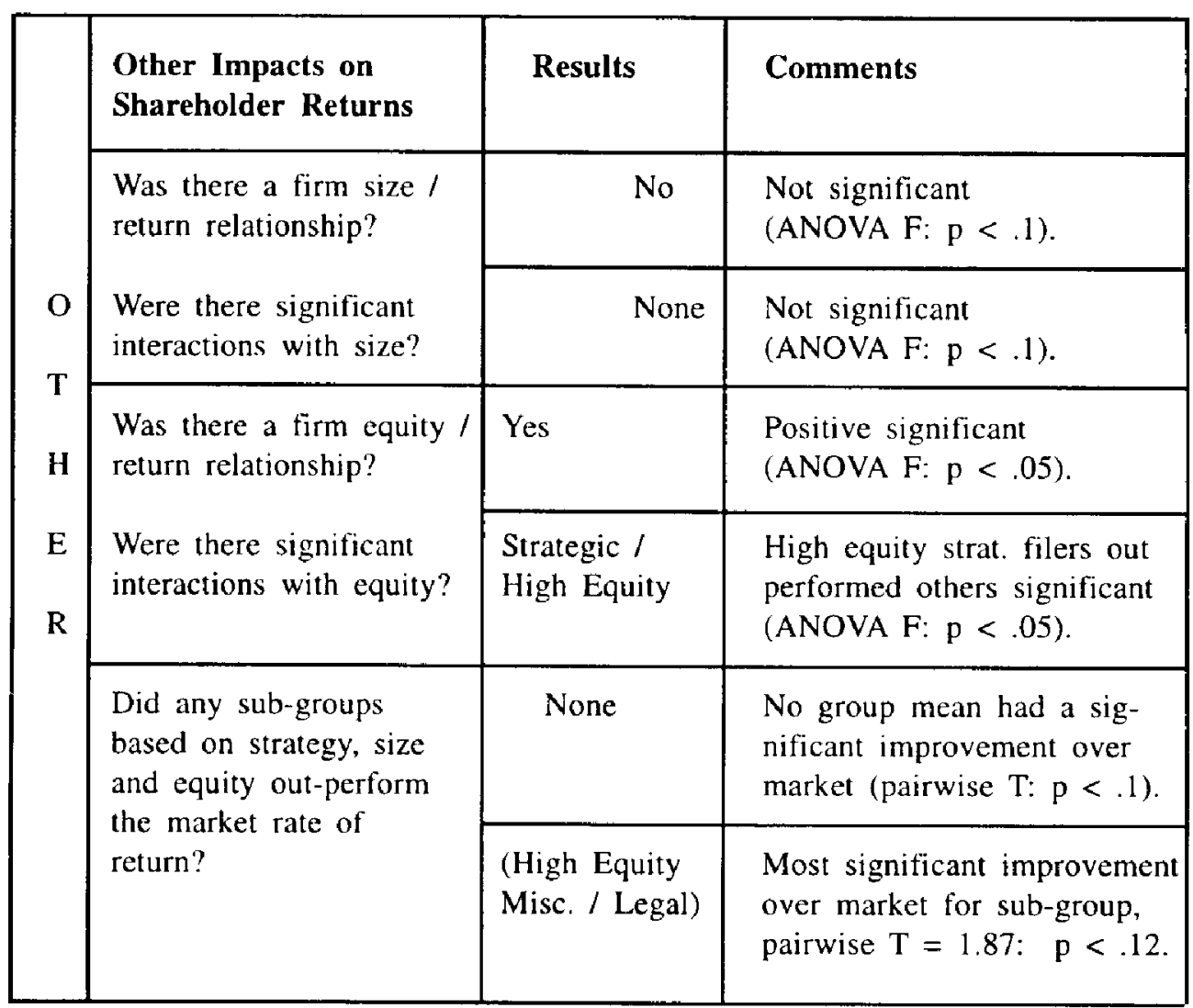

In general, Table 7 shows that a larger firm equity base can help shareholders realize more of their investment. Size does not significantly impact these other factors. In any case, only very rarely did shareholders of bankrupt firms realize returns that were greater than the market rate. This result was generally true for both strategic and non-strategic bankruptcies.

\section{Discussion}

Shareholders can make high rates of return in the year following a Chapter 11 filing according to Sirower (1991). The present study looked at the longer run return to shareholders - more than five years. In theory, management should be managing the company for the long run benefit of the shareholders ( $\mathrm{Hax}$ and Majluf, 1984). Did Chapter 11 bankruptcy - particularly strategic bankruptcy - aid shareholder returns? Were there other conditions that may have helped shareholders earn higher long run returns? 


\section{Synopsis of the Results}

Generally, Chapter 11 filers are poor long run investments. If one invested equal amounts in each of the 155 companies studied here in the month they went bankrupt, the return on investment would average substantially below what one could have obtained by investing in long term risk-free investments during the same time period. Given the risk involved in investing in these types of firms, the long-run return is very low.

Strategic bankruptcies, in general, had below market returns. Only single lawsuit cases had significantly higher returns than market. In the single lawsuit cases, investors may have simply over-estimated the ability of the main creditor to press its claims against the debtor where the debtor was about to file for Chapter 11 reorganization. Possibly, the fact that the solution to the firm's problems was simple and obvious (re-negotiate the amount of the claim down to an amount the company could afford to pay) that it could be dealt with in a far more easy and legally inexpensive way than investors would have predicted.

Size and reorganization success were found to be strongly related to one another in Moulton and Thomas' (1993) work. They defined successful reorganizations as those where the firm maintained its identity, continued to be publicly traded on a national exchange and kept at least half its pre-bankruptcy assets. The firms with the highest returns in the present study - Lafaytte Radio and Sam Soloman - would not have qualified as even partially successful companies for Moulton and Thomas. Both firms were sold: Lafaytte to Circuit City and Sam Soloman to Service Merchandise. The difference in results between Moulton and Thomas' study and the present one may be the result of the differences in how one defines success. In other words, size may be important in allowing a firm to keep its identity, but it has no effect with regard to maximizing shareholders' returns.

There is another way this difference between survival and returns may impact the results. Large size may cause higher numbers of firms with low average returns to survive. Small firms may be less likely to survive but those that do could have higher average returns. This is in fact the case with the present study. While shares in $69 \%$ of small firms became worthless, only $44 \%$ of shares in large firms became worthless (as shown in Appendix 4, cross-tabs Chi ${ }^{2}$ of 8.93 is significant at .01). Among the non-worthless firms, large firms had a somewhat lower annual return to shareholders than smaller firms (though not significantly so). Small firms had an annual return of -.3 and large firms had an annual return of -1.03 . Why might this happen?

Large companies may have the reputational capital to insure proper funding support (D'Aveni 1989) but their relatively more mechanistic structures (Staw, et. al., 1981) may cause great delay in their developing of plans that could stop the downward spiral of decline soon after their filing (Hambrick and D'Aveni, 1988). These firms thus have substantial organizational inertia which better insures their existence but inhibits their ability to change (Hannan and Freeman, 1984). This 
would be so even when they are under extreme pressure to change (Zajac and Kraatz, 1993) - as is the case in a bankruptcy filing. Thus, these firms produce relatively poor average returns.

Conversely, small firms may lack reputational capital to insure proper funding (D'Aveni, 1989) but they may be able to change more quickly due to more organic structures (Sutton and D'Aunno, 1989) and lower organizational inertia (Hannan \& Freeman, 1984). Also, small firms may be able to attract new investors who can purchase sufficient equity in the company so that old management can be forced out. This situation would not only provide new capital for a fresh start but also allows the company to bring in people better able to develop new strategies (Slatter, 1984) to break the firm free of its downward spiral (Hotchkiss, 1995). So, it is evident that fewer small firms survive, but the ones that do have higher returns. The net effect is that the average return among these firms will be poor due to the significant number of worthless ones.

Thus, the inertial forces which aid the large firm's survival (e.g. reputational capital) are balanced out by those which hinder change (e.g. mechanistic structures). Likewise, inertial forces which defeat the small firm's survival (e.g. lack of reputational capital) are balanced out by those which promote change (e.g. organic structures).

Equity was found to be far more important than size in aiding positive shareholder returns. The impact of equity on returns likely stems from two sources. One is the simple point that a stronger equity base is a foundation upon which a restructured company can be built (Sheppard, 1994a). Two, equity allows shareholders some ability to pursue their claims against the company. If there is little to no equity in the company, shareholders fail to be "real parties in interest" at filing (Sabin, Neporent and Weiner, 1991). Without equity, courts could, in theory, block the rights stockholders may have in the bankruptcy proceedings - including the rights to any claims on the firm or its assets (Sabin, et. al., 1991). Thus, higher levels of equity may simply serve to allow shareholders to better maintain their claims against the company?

The interaction of equity and strategy was found to be significant in aiding positive shareholder returns. Flynn and Faird (1991) argued that there are circumstances under which early bankruptcy filing may be the best way to maximize shareholder wealth. The present study found that shareholders of strategic early filers - i.e. firms with high equity, filing a strategic bankruptcy - achieved positive returns. However, since the returns were not significantly above the market rate, there is relatively weak support for early filing. This result leads to two questions. One, why was there any effect from the equity / strategy interaction on returns? Two, why were these effects not more significant?

There are two points to remember. One, a strategic bankruptcy is invoked to proactively deal with a single threat from an identifiable stakeholder group (Daily, 1994). By nature, the strategic bankruptcy is an expedient device to deal with a relatively simple problem (e.g. the threat posed by one lawsuit). Two, the presence or absence of organizational slack (Cyert and March, 1963) in the 
form of equity base (Sheppard, 1994b) alters the organizations' response to threats. Bozeman and Slusher $(1979,346)$ note that "Scarcity-induced stress causes organizations to behave as if complex, dynamic and interrelated environments are in fact simple, static and unrelated."

So, the forces at work are: (1) the simplicity of the problem and (2) the resource base available to deal with the problem. High equity strategic filers would therefore be under less stress due to higher levels of resources (Staw, et. al., 1981). Yet, like many firms in crisis, they would respond by restricting information gathering and alternatives (Smart and Vertinsky, 1977). By doing so, they quickly focus on the simple and obvious solutions to what may be simple and obvious problems. This appropriate response is in contrast to low equity non-strategic filers. These firms would be under more stress due both to a scarcity of resources and a set of problems and solution alternatives that taxes their information processing capabilities (Staw, et. al., 1981). By restricting information gathering and alternatives, such companies would be less likely to be come to decisions which would allow them to properly allocate resources and break free of their downward spiral (Argenti, 1986a and 1986b; Hambrick and D'Aveni, 1988)

Why would equity and strategy not result in returns to shareholders significantly above market? It is possible that either (1) investors could not correctly estimate the corporation's likelihood of Chapter 11 filing or (2) they could not correctly estimate the effects that the filing would have upon their investment. In the first case, the filing might have taken investors by surprise and any possible impacts (positive or negative) from filing may not have been factored into the price. This is unlikely since there are many early warning signs of failure that investors could have identifed (e.g. see Argenti, 1986a and 1986b). It is more likely that the investors incorrectly estimated the outcome of the bankruptcy process for firms in this category. Being uncertain of how the courts would interpret the new bankruptcy statutes, investors could not have correctly estimated the value of the stock.

\section{Implications for Practice}

What do these results mean for investors of companies facing a Chapter 11 filing? First, investors should, in general, avoid these stocks as long term investments. The average return on investment here was substantially below the risk-free rate. Second, the presence of a high return category of strategic bankruptcy indicates some limited opportunity for significant returns above the risk free rate. Miscellaneous / Legal strategic bankruptcies may provide investors with a positive return - particularly in cases where the company is attempting to use Chapter 11 to defend itself against the impacts from a single lawsuit. However, the positive returns found here may be fleeting. When the bankruptcy law was new there may have been uncertainties regarding how the law would impact some types of filings. The price may have been distorted as to allow for some posi- 
tive returns. With investors having better knowledge of how the bankruptcy process works, the price distortion, along with possibilities for positive returns, may be gone. Finally, company size does not matter for the investor seeking high returns but for managers seeking corporate survival.

Managers should be aware that early filing is advantageous. Thus, as soon as managers realize that filing is inevitable, it is in the best interest of shareholders that it is done expeditiously. This outcome holds particularly for companies with a high equity base and problems that Chapter 11 can easily address (i.e. early filing strategic bankrupt companies). These companies may be best at achieving some sort of positive outcome from the bankruptcy process for their investors. The high returns for such filings may also suggest that there are circumstances where the threat-rigidity response may work in favor of an organization in crisis (as suggested by Staw, et. al., 1981). As previously suggested, such a response would serve to simplify the set of alternative problem solutions under circumstances where such simplification is most appropriate and resources for implementation still exist. Finally, managers of smaller firms going into Chapter 11 should not be totally disheartened - provided their company was a strategic early filer. Though not significantly better than the market, small companies with early filing of strategic bankruptcies had the best rate of return.

\section{Limitations}

As in all studies, there are some limitations to the present research which must be discussed. These include factors regarding definition, sample composition and time period studied, alternatives that may have served Chapter 11 filers better, and learning by investors or courts after the period of study.

The definition for strategic bankruptcy used here is a broad one and a narrowly-defined one may give different success results. However, a narrower definition may not cover as many possibilities open to managers who wish to pursue strategic bankruptcy. Also, given the sample size available, a narrow definition would not lend itself well to testing. Also, different interpretations of the available data might have resulted in different firm classifications. The exploratory nature of the present study did not allow for a more complete search of all possible data sources.

Sample composition may have also had an impact on the results. The minimum size and age limits set for sample firms could mean that younger or smaller firms may be at greater risk than the present analysis indicates. Hambrick and D'Aveni (1988) note this possibility as well.

There are two important items of note about the time period selected. First, in an effort to ensure firms made it through their Chapter 11 proceedings, no firms which initially filed after 1987 were included in the study. Since prepackaged bankruptcies, or "pre-packs" are a new twist to Chapter 11 in the last five years there are no pre-packs in the sample. The success likelihood of this particular category of strategic bankruptcies will thus require further study. Second, some 
firms re-entered bankruptcy after 1987 but have not yet come out of Chapter 11 . Such firms were considered to be worthless since there was likely little that would be left for shareholders after a second round of Chapter 11 proceedings - though the full impact of the second filing is unknown. Less than $5 \%$ of the firms in the sample were second filings after $1987 .^{9}$

Alternatives that may serve shareholders better than Chapter 11 may exist. Returns to investors in companies that managed turnarounds or arranged workouts with their creditors versus returns to shareholders of companies that filed were not studied. For this reason, early or strategic filing cannot be wholeheartedly supported. For example, it is unknown how well a company could have done with a debt-for-equity swap as opposed to a Chapter 11 reorganization.

Learning by investors may change opportunities for future profitable shareholder returns. The results of the present study may simply demonstrate the failure of the market to price the stock correctly at filing. This failure may have occurred since investors had to deal with a new law (the 1978 Bankruptcy Act) that had yet to be interpreted. As bankruptcy case law has built up over the years, investors should have improved their ability to evaluate good strategic bankruptcies. The opportunity for excess returns may have been a fleeting one brought on by a change in the law. In the future, investors may have to look for some new revisions to find future positive returns. Also, the courts may interpret the law more narrowly in the future. For example, if the bankruptcy courts begin to lean toward the plaintiff's side in mass tort or single lawsuit cases, the parts of the broken bench which seemed beautiful may instead provide investors with some painful splinters.

\section{Directions for Future Research}

Several avenues for future research present themselves as a result of the present study. These inquiries would deal with returns regarding specific types of bankruptcies, alternatives to bankruptcy, organizational response to the Chapter 11 filing, and learning by investors.

The present study found the value of strategically filing for bankruptcy in general to be questionable. However, research into the category of Miscellaneous / Legal strategic bankruptcies, high equity strategic bankruptcies, or pre-packaged bankruptcies may be fruitful avenues for looking into circumstances where Chapter 11 could enrich shareholders. Of particular interest may be the returns to shareholders when the firm is merged into another after Chapter 11. The firms with the highest shareholder returns in the present study fell into this category

While it was beyond the scope of the present study, investigation into the returns to shareholders of declining corporations that sought to move away from ruin by other methods may prove an interesting area of study. For example, a financial restructuring or workout arrangement with creditors may have provided better returns for shareholders. 
The organizational responses that cause some Chapter 11 filers to become worthless and others to have returns above the market need to be studied. How the combination of organizational inerita and managerial paralysis or rigidity work within the organization that has filed for Chapter 11 reorganization may have great impact upon returns to shareholders.

Finally, the ability of investors to learn from prior court decisions could be studied to see if returns on these type of investments decline as the market learns how to interpret the impact of the law. As the law in this area becomes clearer returns should begin to approach zero relative to the market. Investors should become better at pricing the stock at filing. Extraordinary returns would thus be less likely to occur in the future since investors have learned which types of strategic filings are likely to be successful and now price the pre-bankruptcy investment accordingly.

\section{Conclusion}

There are some types of strategic bankruptcies which can result in positive returns to shareholders. However, the number of high return types is low and the extent to which these types provide shareholders with returns that are significantly above market is limited. Returns to shareholders of companies that either merged after Chapter 11 filing, or sought alternatives to bankruptcy could be fruitful avenues for future research. Finally, what the present research shows is the importance of having some useful guide - in this case a typology - to find a way around the confusing landscape of strategic bankruptcies. Like the streets of Venice, it is easy to get lost without a map, and hopefully the present research provides one.

\section{Endnotes}

1 In a sense, stakeholders become competitors for the company's assets.

2 On the surface, some strategic bankruptcies against creditors often appear to be filings for straightforward stays as well. However, the difference between the strategic and nonstrategic bankruptcies in these cases is that the non-strategic ones are using the stay to develop a plan to reorganize and the strategic ones have already developed a plan whose implementation the creditors were unwilling to support. The strategic filing is thus a way to force that support and allow for the full implementation of the plan. As will become clearer, in-depth analysis of the press reports of these types of strategic filers reveals a complex underlying strategy, or ploy. Analysis of press reports on non-strategic filers does not reveal the same machinations.

3 An example of using Chapter 11 against a non-traditional creditor would be the use of bankruptcy by Manville Corp. (successor to Johns Manville) to sort out thousands of asbestos claims which could have been potentially filed against the company. An example of a strategic use of Chapter 11 against a traditional creditor would be Magic Circle Energy's attempt to use bankruptcy to force its bank to release real estate collateral to allow oil drilling. 
4 The simple annual percentage returns to shareholders used here represent excess returns over the risk free rate. Analysis was also performed to evaluate excess returns relative to investments with a somewhat higher degree of risk, i.e. change in the Dow Industrial Average from the time of Chapter 11 filing until the end of 1992. When the Dow figures were substituted for the average market the results did not differ significantly from the results of the study shown here.

5 The numbers employed were the transformed returns. The transformations were designed to reduce the impact of outliers. The numbers were transformed using the square root of the absolute value of their percentage returns. In order to maintain the variables' signs these values were multiplied by the untransformed value over the absolute value of the untransformed value.

6 On average, the shareholder returns for firms filing for strategic bankruptcies dealing with capital providers or the government had significantly lower rates of return than the market $(p<.001$ via pairwise T-test comparing average shareholder returns to average market returns).

7 However, due to the legal wrangling likely to occur, courts do not typically try to exclude stockholders from the bankruptcy proceedings when there is little to no equity. 8 This would explain the high returns for firms entering Chapter 11 to settle single lawsuit cases.

9 These firms were CS Group in 1989; Salant in 1990; Lionel in 1991; Combustion Equipment in 1992; and Tacoma Boat in 1993.

\section{References}

Altman, E. I. "Financial ratios, discriminant analysis and the prediction of corporate bankruptcy." Journal of Finance 23 (Dec. 1968): 589-609.

Argenti, J. Corporate Collapse: The Causes and Symptoms. New York: John-Wiley, 1976.

"Predicting corporate failure." Accountancy (April 1986a): 157-8.

2.

"Spot danger signs before it's too late." Accountancy (July 1986b): 101-

Agresti, A. and B. F. Agresti. Statistical Methods for the Social Sciences. San Francisco: Dellen Publishing, 1979.

Bozeman, B. and E. A. Slusher. "Scaricity and environmental stress in public organizations: A conjectural essay." Administration and Society 2 (1979): 335-55.

Brown, D. T. "Claimholder incentive conflicts in reorganization: The role of bankruptcy law." The Review of Financial Studies 2 (1989): 109-23.

Cifelli, A. "Management by bankruptcy." Fortune (October 31, 1983): 69-72.

Chen, K. U. and T. A. Shimerda. "An Empirical Analysis of Useful Ratios." Financial Management 10 (Spring 1981): 51-60. 
Cyert, R. and J. G. March. A Behavioral Theory of the Firm. Englewood Cliffs, NJ: Prentice Hall, 1963.

Daily, C. M. "Bankruptcy in strategic studies: Past and promise." Journal of Management 20 (Summer 1994): 263-95.

D'Aveni, R. "Dependability and organizational bankruptcy: An application of agency and prospect theory." Management Science 59 (Sept. 1989): 1120-38.

Delaney, K. J. Strategic Bankruptcy: How Corporations and Creditors use Chapter 11 to Their Advantage. Berkeley, CA: University of California Press, 1992.

Duncan, J. W. "Business failures post sharpest increase since 1983." D and B Reports (May-June, 1991): S1-S3.

Flynn, D. M. and M. Faird. "The intentional use of Chapter XI: Lingering versus immediate filing." Strategic Management Journal 12 (Feb, 1991): 63-74.

Hambrick, D. C. and R. A. D'Aveni. "Large corporate failures as downward spirals." Administrative Science Quarterly 33 (Spring 1988): 1-23.

Harrigan, K. R. "Research methodologies for contingency approaches to business strategy." Academy of Management Review 8 (May 1983): 398-405.

Hannan, M. T. and J. Freeman. "Structural Inertia and Organizational Change." American Sociologal Review 49 (April 1984): 149-64.

Hax, A. C. and N. S. Majluf. Strategic Management. An Integrated Approach. Englewood Cliffs, NJ: Prentice-Hall, 1984.

Hoffer, C. W.. "Toward a Contingency Theory of Business Strategy." Academy of Management Journal 18 (Oct. 1975): 784-810.

Hotchkiss E. S. "Postbankruptcy performance and management turnover." Journal of Finance 50 (Jan. 1995): 3-21.

Miles, R. E. and C. C. Snow. Organizational Strategy, Structure and Process. New York: McGraw-Hill, 1978.

Miller, D. and P. Friesen. "Archetypes of organizational transition." Administrative Science Quarterly 25 (Fall 1980): 591-614.

Mintzberg, H. "Five Ps for strategy." In The Strategy Process Concepts, Contexts. Cases 2nd Ed. Eds. H. Mintzberg and J. B. Quinn. Englewood Cliffs, NJ: Prentice Hall, 1991. 
Moulton W. N. and H. Thomas. "Bankruptcy as a deliberate strategy: Theoretical considerations and empirical evidence." Strategic Management Journal 14 (Feb. 1993): 12535 .

Mun, G. G. and F. L. Garcia. Encyclopedia of Banking and Finance 8th Edition. Boston: Bankers Book Co., 1983.

Norusis, M. J. SPSS/PC+ Advanced Statistics. Chicago: SPSS Inc., 1988.

Owen, B. and R. Brautigam. The Regulation Game: Strategic Use of the Administrative Process. Cambridge, Mass: Ballinger Publications, 1980.

Pinches, G. E. and K. A. Mingo. "A Multivariate Analysis of Industrial Bond Ratings." Journal of Finance 38 (Jan. 1973): 1-18.

Porter, M. E. Competive Strategy. Techniques for Analyzing Industries and Competitors. New York: Free Press, 1980.

Rumelt, R. P. Strategy. Structure and Economic Performance. Cambridge, Mass.: Division of Research, Harvard Business School, 1974.

Sabin, J., M. Neporent and C. Weiner. "Legal considerations of purchasing securities." Workouts \& Turnarounds: The Handbook of Restructuring \& Investing in Distressed Companies. Eds. D. DiNapoli, S. Sigoloff and R. Cushman Homewood IL: Business 1 Irwin, 1991.

Sheppard, J. P. "When the going gets tough, the tough go bankrupt: The questionable use of Chapter 11 as a strategy." Journal of Management Inquiry 1 (Fall, 1992): 183-92.

Strategic Bankruptcy: Typology and Success Likelihood Discussion Paper, Simon Fraser University, 1994a.

"Strategy and bankruptcy: An exploration into organizational death." Journal of Management 20 (Winter 1994b): 795-833.

Sherman, S. P. “Bankruptcy's spreading blight.” Fortune (June 3 1991): 123 - 132.

Singh, J. V. and C. J. Lumsden. "Theory and research in organizational ecology." In The Annual Review of Sociology Eds. W. R. Scott \& J. Blake, Palo Alto, CA: Annual Reviews, 1990.

Sirower, M.. "Bankruptcy as a strategic planning tool." In Academy of Management Best Papers Proceedings Eds. J. L. Wall and L. R. Jauch, Ada, OH: Academy of Management, 1991.

Slatter, S. Corporate Recovery: Successful Turnaround Strategies and Their Implementation. Harmondsworth, Middlesex, England: Penguin Books, 1984. 
Smart, C. and I. Vertinsky. "Designs for Crisis Decision Units." Administrative Science Quarterly 22 (Fall 1977): 640-57.

Smith, K. G., J. P. Guthrie and M. J. Chen. "Strategy size and performance." Organization Studies 10 (Jan 1989): 63-81.

Staw, B. M., L. E. Sandelands and J. E. Dutton. "Threat-rigidity effects in organizational behavior: A multilevel analysis." Administratjve Science Quarterly 32 (Spring 1981): 542569.

Sutton R. I. and T. D'Aunno. "Decreasing organizational size: Untangling the effects of money and people." Academy of Management Review 14 (Summer 1989): 194-212

Zajac, E. J. and M. S. Kraatz. "A diametric forces model of strategic change: Assessing the antecedents and concequences of restructuring in the higher education industry." Strategic Management Journal 14 (Spring 1993): 83-102. 
Appendix 1: List of Non-Strategic Bankrupt Firms

\begin{tabular}{|c|c|c|c|c|c|}
\hline $\begin{array}{l}\text { Filing } \\
\text { Company } \\
\text { Name }\end{array}$ & $\begin{array}{l}\text { Filing } \\
\text { Year }\end{array}$ & $\begin{array}{l}\text { Filing } \\
\text { Company } \\
\text { Name }\end{array}$ & $\begin{array}{l}\text { Filing } \\
\text { Year }\end{array}$ & $\begin{array}{l}\text { Filing } \\
\text { Company } \\
\text { Name }\end{array}$ & $\begin{array}{l}\text { Filing } \\
\text { Year }\end{array}$ \\
\hline AIC Photo & 1985 & $\begin{array}{l}\text { General } \\
\text { Exploration }\end{array}$ & 1986 & $\begin{array}{l}\text { Poloron } \\
\text { Products }\end{array}$ & 1981 \\
\hline $\begin{array}{l}\text { AM } \\
\text { International }\end{array}$ & 1982 & $\begin{array}{l}\text { Geophysical } \\
\text { Systems }\end{array}$ & 1983 & Pubco & 1982 \\
\hline ATI & 1984 & Gilman Services & 1982 & RPS Products & 1982 \\
\hline Advent & 1981 & $\begin{array}{l}\text { Gilpin } \\
\text { (Henry B.) }\end{array}$ & 1980 & $\begin{array}{l}\text { Reading } \\
\text { Industries }\end{array}$ & 1981 \\
\hline $\begin{array}{l}\text { Allied } \\
\text { Technology }\end{array}$ & 1980 & Glover & 1980 & $\begin{array}{l}\text { Richmond } \\
\text { Tank Car }\end{array}$ & 1983 \\
\hline $\begin{array}{l}\text { American } \\
\text { Monitor }\end{array}$ & 1985 & Goldblatt Bros. & 1981 & Robintech & 1983 \\
\hline $\begin{array}{l}\text { Amfesco } \\
\text { Industries }\end{array}$ & 1985 & $\begin{array}{l}\text { Good (I.S.) } \\
\& \text { Co. }\end{array}$ & 1980 & $\begin{array}{l}\text { Roblin } \\
\text { Industries }\end{array}$ & 1985 \\
\hline $\begin{array}{l}\text { Argo } \\
\text { Petroleum }\end{array}$ & 1985 & $\begin{array}{l}\text { Hardwicke } \\
\text { Companies }\end{array}$ & 1983 & $\begin{array}{l}\text { Ronco } \\
\text { Teleproducts }\end{array}$ & 1984 \\
\hline $\begin{array}{l}\text { Barclay } \\
\text { Industries }\end{array}$ & 1981 & $\begin{array}{l}\text { Imperial } \\
\text { Industries }\end{array}$ & 1986 & $\begin{array}{l}\text { SAL } \\
\text { Communications }\end{array}$ & 1985 \\
\hline $\begin{array}{l}\text { Beker } \\
\text { Industries }\end{array}$ & 1985 & $\begin{array}{l}\text { Inflight } \\
\text { Services }\end{array}$ & 1986 & Seiscom Delta & 1986 \\
\hline $\begin{array}{l}\text { Berry } \\
\text { Industries }\end{array}$ & 1984 & $\begin{array}{l}\text { John F. } \\
\text { Lawhon }\end{array}$ & 1981 & $\begin{array}{l}\text { Servamatic } \\
\text { Systems }\end{array}$ & 1986 \\
\hline $\begin{array}{l}\text { Berven } \\
\text { Carpets }\end{array}$ & 1982 & Koss & 1984 & $\begin{array}{l}\text { Shelter } \\
\text { Resources }\end{array}$ & 1982 \\
\hline $\begin{array}{l}\text { Birdview } \\
\text { Satellite }\end{array}$ & 1986 & $\begin{array}{l}\text { K-Tel } \\
\text { International }\end{array}$ & 1984 & $\begin{array}{l}\text { Spencer } \\
\text { Companies }\end{array}$ & 1986 \\
\hline $\begin{array}{l}\text { Bobbie } \\
\text { Brooks }\end{array}$ & 1982 & $\begin{array}{l}\text { Leisure } \\
\text { Dynamics }\end{array}$ & 1983 & Spiral Metal & 1983 \\
\hline
\end{tabular}


Appendix 1: List of Non-Strategic Bankrupt Firms (cont"d)

\begin{tabular}{|c|c|c|c|c|c|}
\hline $\begin{array}{l}\text { Filing } \\
\text { Company } \\
\text { Name }\end{array}$ & $\begin{array}{l}\text { Filing } \\
\text { Year }\end{array}$ & $\begin{array}{l}\text { Filing } \\
\text { Company } \\
\text { Name }\end{array}$ & $\begin{array}{l}\text { Filing } \\
\text { Year }\end{array}$ & $\begin{array}{l}\text { Filing } \\
\text { Company } \\
\text { Name }\end{array}$ & $\begin{array}{l}\text { Filing } \\
\text { Year }\end{array}$ \\
\hline $\begin{array}{l}\text { Brody (B.) } \\
\text { Seating }\end{array}$ & 1980 & Lionel & 1982 & $\begin{array}{l}\text { Standard } \\
\text { Metals }\end{array}$ & 1984 \\
\hline $\begin{array}{l}\text { Buttes Gas } \\
\& \text { Oil }\end{array}$ & 1985 & Lynnwear & 1981 & Steelmet & 1983 \\
\hline CS Group & 1982 & $\begin{array}{l}\text { Macrodyne } \\
\text { Industries }\end{array}$ & 1986 & Stevcoknit & 1981 \\
\hline $\begin{array}{l}\text { Charter } \\
\text { Corp. }\end{array}$ & 1984 & $\begin{array}{l}\text { Magic } \\
\text { Marker }\end{array}$ & 1980 & $\begin{array}{l}\text { Storage } \\
\text { Technology }\end{array}$ & 1984 \\
\hline $\begin{array}{l}\text { Combustion } \\
\text { Equipment }\end{array}$ & 1980 & $\begin{array}{l}\text { Magnuson } \\
\text { Computer }\end{array}$ & 1983 & $\begin{array}{l}\text { Sykes } \\
\text { Datatronics }\end{array}$ & 1985 \\
\hline $\begin{array}{l}\text { Consolidated } \\
\text { Package }\end{array}$ & 1984 & $\begin{array}{l}\text { Marion } \\
\text { Corp. }\end{array}$ & 1983 & $\begin{array}{l}\text { Tacoma } \\
\text { Boatbuilding }\end{array}$ & 1985 \\
\hline $\begin{array}{l}\text { Consolidated } \\
\text { Petrol. }\end{array}$ & 1984 & $\begin{array}{l}\text { Maxon } \\
\text { Industries }\end{array}$ & 1981 & Tenna Corp. & 1979 \\
\hline $\begin{array}{l}\text { Crutcher } \\
\text { Resources }\end{array}$ & 1986 & Mays, J.W. & 1982 & Texscan & 1985 \\
\hline Crystal Oil & 1986 & $\begin{array}{l}\text { Michigan } \\
\text { General }\end{array}$ & 1987 & $\begin{array}{l}\text { Todd } \\
\text { Shipyards }\end{array}$ & 1987 \\
\hline $\begin{array}{l}\text { Dalco } \\
\text { Petroleum }\end{array}$ & 1983 & $\begin{array}{l}\text { Monolith } \\
\text { Portland }\end{array}$ & 1986 & Towle Mfg. & 1986 \\
\hline $\begin{array}{l}\text { Dant \& } \\
\text { Russell }\end{array}$ & 1982 & $\begin{array}{l}\text { Morton } \\
\text { Shoe }\end{array}$ & 1982 & $\begin{array}{l}\text { Towner } \\
\text { Petroleum }\end{array}$ & 1984 \\
\hline $\begin{array}{l}\text { Data Access } \\
\text { Systems }\end{array}$ & 1983 & $\begin{array}{l}\text { National } \\
\text { Shoes }\end{array}$ & 1980 & $\begin{array}{l}\text { Travel } \\
\text { Equipment }\end{array}$ & 1980 \\
\hline $\begin{array}{l}\text { Eagle } \\
\text { Computer }\end{array}$ & 1986 & $\begin{array}{l}\text { Nexus } \\
\text { Industries }\end{array}$ & 1985 & UNA Corp. & 1986 \\
\hline
\end{tabular}


Appendix 1: List of Non-Strategic Bankrupt Firms (cont"d)

\begin{tabular}{|l|c|l|l|l|c|}
\hline $\begin{array}{l}\text { Filing } \\
\text { Company } \\
\text { Name }\end{array}$ & $\begin{array}{l}\text { Filing } \\
\text { Year }\end{array}$ & $\begin{array}{l}\text { Filing } \\
\text { Company } \\
\text { Name }\end{array}$ & $\begin{array}{l}\text { Filing } \\
\text { Year }\end{array}$ & $\begin{array}{l}\text { Filing } \\
\text { Company } \\
\text { Name }\end{array}$ & $\begin{array}{l}\text { Filing } \\
\text { Year }\end{array}$ \\
\hline Edmos & 1983 & $\begin{array}{l}\text { Nicklos Oil } \\
\text { \& Gas }\end{array}$ & 1985 & Unimet & 1985 \\
\hline $\begin{array}{l}\text { Evans } \\
\text { Products }\end{array}$ & 1985 & Nucorp & 1982 & Upson & 1980 \\
\hline $\begin{array}{l}\text { First } \\
\text { Hartford }\end{array}$ & 1981 & OxOCO & 1986 & $\begin{array}{l}\text { Van Wyke } \\
\text { Internatl. }\end{array}$ & 1980 \\
\hline $\begin{array}{l}\text { Flame } \\
\text { Industries }\end{array}$ & 1983 & Opelika Mfg. & 1985 & $\begin{array}{l}\text { Victoria } \\
\text { Station }\end{array}$ & 1986 \\
\hline Garland & 1980 & $\begin{array}{l}\text { Penn-Dixie } \\
\text { Industries }\end{array}$ & 1980 & $\begin{array}{l}\text { Winn } \\
\text { Enterprises }\end{array}$ & 1986 \\
\hline $\begin{array}{l}\text { Gateway } \\
\text { Sporting }\end{array}$ & 1981 & $\begin{array}{l}\text { Pettibone } \\
\text { Corp. }\end{array}$ & 1986 & Xonics & 1984 \\
\hline Theater & 1984 & Time & & \\
\hline
\end{tabular}


Appendix 2: Post Chapter 11 Filing Company Name Changes

\begin{tabular}{|c|c|}
\hline Pre-Ch. 11 Filing Name & Post-Ch. 11 Filing Name \\
\hline AIC Photo & AIC International \\
\hline American Monitor & AM Diagnostics \\
\hline ATI Inc. & ATI Pharmaceutical \\
\hline Allied Technology & Technological Sciences \\
\hline Amfesco Industries & New American Shoe \\
\hline Argo Petroleum & Fortune Petroleum \\
\hline Berry Industries & Strata Search Inc. \\
\hline Combustion Equip. Assoc. & Carter Day Industries \\
\hline Data Access System & Authorized Distribution \\
\hline Edmos Corp. & Bangor America \\
\hline Evans Products & Grossman Lumber \\
\hline Gateway Sporting Goods & Gateway Gathering Sys. \\
\hline Goldblatt Brothers & JG Industries \\
\hline Heck's Inc. & Hallwood Holdings \\
\hline John F. Lawhon Furniture & W \& J Sloane Co. \\
\hline Magic Circle Energy & MCE Inc. \\
\hline McLouth Steel & MLX Industries \\
\hline Mego International & Mego Corp. \\
\hline Mesta Machine & Mestek \\
\hline Mobile Home Industries & MHI Group \\
\hline
\end{tabular}


Appendix 2: Post Chapter 11 Filing Company Name Changes (cont'd)

\begin{tabular}{|l|l|}
\hline Pre-Ch. 11 Filing Name & Post-Ch. 11 Filing Name \\
\hline Morton Shoe & Morton Co.s Transport \\
\hline Northwest Engineering & Terex \\
\hline OXOCO & Ironstone Group \\
\hline Penn-Dixie & Continental Steel \\
\hline Sambos Restaurants & SRI Holdings \\
\hline Transcontinental Energy & Regency Affiliates \\
\hline Van Wyke International & Robeson Industries \\
\hline Wheeling-Pittsburgh Steel & Wheeling Pittsburgh Co. \\
\hline White Motor & EnviroSource Inc. \\
\hline
\end{tabular}


Appendix 3: Post Chapter 11 Returns

\begin{tabular}{|l|l|l|l|l|l|l|}
\hline \multirow{2}{*}{$\begin{array}{l}\text { Shareholder } \\
\text { Returns }\end{array}$} & \multicolumn{2}{|c|}{ All Bankruptcies } & \multicolumn{2}{c|}{$\begin{array}{l}\text { Strategic } \\
\text { Bankruptcies }\end{array}$} & \multicolumn{2}{c|}{$\begin{array}{l}\text { Non-Strategic } \\
\text { Bankruptcies }\end{array}$} \\
\cline { 2 - 7 } & $\mathbf{N}$ & Mean & N & Mean & N & Mean \\
\hline Total Bankruptcies & 155 & -2.95 & 55 & -1.17 & 100 & -3.92 \\
\hline Small Bankruptcies & 78 & -3.27 & 19 & -0.88 & 59 & -4.04 \\
\hline Large Bankruptcies & 77 & -2.62 & 41 & -3.76 & 36 & -1.33 \\
\hline $\begin{array}{l}\text { Low Equity } \\
\text { Bankruptcies }\end{array}$ & 78 & -3.71 & 27 & -2.95 & 51 & -4.11 \\
Small Bankruptcies & 38 & -3.95 & 8 & -3.67 & 30 & -4.05 \\
Large Bankruptcies & 40 & -3.48 & 19 & -2.68 & 21 & -4.19 \\
\hline $\begin{array}{l}\text { High Equity } \\
\text { Bankruptcies }\end{array}$ & 77 & -2.18 & 28 & $\mathbf{0 . 5 3}$ & 49 & -3.73 \\
Small Bankruptcies & 40 & -2.62 & 11 & $\mathbf{1 . 0 7}$ & 29 & -4.02 \\
Large Bankruptcies & 37 & -1.70 & 17 & $\mathbf{0 . 1 9}$ & 20 & -3.30 \\
\hline
\end{tabular}

Appendix 4: Worthless/Non-Worthless Shares by Firm Asset Size

\begin{tabular}{|c|c|c|c|}
\hline & \multirow{5}{*}{$\begin{array}{l}\text { Worthless } \\
\text { Non-Worthless }\end{array}$} & Asset & Size \\
\hline & & Large & Small \\
\hline \multirow{3}{*}{$\begin{array}{l}\mathbf{S} \\
\mathbf{h} \\
\mathbf{a} \\
\mathrm{r} \\
\mathrm{e} \\
\mathrm{s}\end{array}$} & & $34(44.2 \%)$ & $54(69.2 \%)$ \\
\hline & & $43(55.8 \%)$ & $24(30.8 \%)$ \\
\hline & & $\mathrm{Chi}^{2}=8.93$ & Sig.@.01 \\
\hline
\end{tabular}

